\title{
Measuring the Performance of e-Primary School Systems in Bangladesh
}

\author{
Dr. Wahiduzzaman Khan \\ Associate Professor, Department of Business Administration, Leading University, \\ Ragibnagar, South Surma, Sylhet-3112, Bangladesh, \\ Email: wzk_roence@yahoo.co.uk \\ *Md. Mahbobor Rahaman \\ Lecturer, Department of Business Administration, Leading University, \\ Ragibnagar, South Surma, Sylhet-3112, Bangladesh, \\ Email: mahbobdumis@gmail.com \\ *Correspondence author (e-mail: mahbobdumis@gmail.com and cell: +8801723347110 )
}

Received: 30 November 2019; Accepted: 25 December 2019; Published: 08 February 2020

\begin{abstract}
The government of Bangladesh (GoB) recently have introduced the concept of Digital Bangladesh. Education is one of the most vital sectors to make the digital nation. For that reason, the GoB has started to convert primary to e-primary schools. The main objective of this study is to investigate the current Information and Communication Technology (ICT) implementation status in e-primary schools by the GoB. The study is quantitative in nature. The study also develops an ICT implementation status model from the eprimary school systems in Bangladesh. This model has identified the ICT equipment, analyzed the ICT support \& equipment, given weighted to each factor and investigated the current state of ICT implementation of eprimary schools in Bangladesh. The study has taken 800 sample schools from 8 divisions to investigate the current ICT implementation status. The study suggested that before implementing the ICT they will make sure all the infrastructure of ICT is available in those primary schools.
\end{abstract}

Index Terms-Information Communication Technology (ICT), e-Primary Schools, Digital Education, e-School Model, Government of Bangladesh (GOB)

\section{INTRODUCTION}

Bangladesh could be a country with an outsized pool of intelligent citizens are often become a valuable human resource with correct education. solely correct education will create a correct, civilized and developed nation [1]. To reform our education sector, arrange the schoolroom surroundings and redesigning the tools of learning is a vital hub [2] easy the data \& Communication Technology (ICT) accelerated reform has been given the utmost importance, as a results of its state and price effectiveness. Being (Government of Bangladesh) GoB's flagship ICT for Development program has so been chosen to guide the reform through ICT primarily based education initiatives [3]. The governments and educators all round the world have recognized or returning to acknowledge the exceptional promise of ICT to foster teaching and learning within the previous decades [4].

The role of ICT within the education sector plays a vital role [5] particularly within the method of empowering the technology into the tutorial activities [6]. This sector is often the foremost effective sector to anticipate and eliminate the negative impact of ICT [7]. Technology are often the foremost effective thanks to increase the student's [8] information and sophistication area participation [9]. Usage of ICT in education adds price in teaching and learning by enhancing the effectiveness of learning method [10]. ICT additional a singular dimension to be told that wasn't antecedently accessible in our country [11], once the beginning of ICT in faculties was started [12], students found learning in an exceedingly technology [13] increased surroundings a lot of stimulating and fascinating than in exceedingly ancient schoolroom surroundings [14].

The new economic and social manner of handling [15] the speedy development of knowledge and communication technologies (ICT) and their wide usage all told areas of life provoke new necessities and changes in education [16] . For many decades computers were remodeled from exotic tools into the image of the society and its progress [17], the foremost necessary part of latest education is that the initial forming and development of competences that give a high level of realization of temperament in very competitive surroundings with relevancy solid information, intelligence [18], mobility, ability, entrepreneurship, and confidence[19] in one's own talents [20]. A competent individual is ready to mix information, skills and attitudes, and to use and create use of previous [21]. National ICT policy of Bangladesh framed in 2009, perceived ICT as suggests that of holistic development of the state $[15,16]$. ICT based mostly education for the long run must accommodate everchanging views of technology and its teaching, and everchanging views of skilled development [22]. The 
National Education Policy, 2010 meant to bring necessary reforms in course of study, pedagogy and teachers' capability building wherever ICT would be an efficient tool [23].

Education system is being progressed for creating [24] science-based, pro-active generation [25], non-communal and progressive nation by increasing the literacy rate of 100 percent, developing digital Bangladesh, by spreading education and improving its quality, Bangladesh has already been promoted to a middle-income nation all over the world [26]. The use of information and communication technologies (ICT) in the education system in accordance with other countries [27], make it modern and work-oriented for proper education [28]. Now, the ruling government has already been worked vastly in every wings of education in the mood of ICT oriented facilities [29], such as, Multimedia classroom have been started in 4 thousand and 500 primary schools and 33 thousand secondary [21], higher secondary and higher level institutions, 21 lakhs teachers are engaged with this system and 7.5 million students are getting better classroom performance of teaching-learning techniques [30]. Near bout 20,000 computer labs have been set up, 1700 computers have already been supplied to the institutions and many teachers have been given foreign training on ICT, ICT Training and Resource Center (UTTRCE) in 125 upazilas has been established, from this ICT Center 37 [31] thousand teachers have been given ICT training in the year 2017 and 2018, computer lab have been set up in 3,544 educational institutions since 2009, computer education has been compulsory for secondary and higher secondary/equivalent level [32], to encourage education and information technology 17 ICT mobile van launched [33], 19 Digital Language Laboratories have been set up and from it training programs have been started [343,35], Computer Aided Learning (CAL) program, as a pilot project, is being operated in 50 schools. The government has done extensive work in the last 10 years in the field of education. ICT in education makes the whole education system modern and significant. Bangladesh is ranked the fifth in Asia to have used the internet most [36], with more than 80 million having internet access as of December 2017[37], up from 0.1 million in 2000 [21]. The ICT oriented class room and class facilities has been started in most of the primary schools in Bangladesh [38].

\section{ObJectives Of The Study}

The main objective of this study is to investigation the implementation status of ICT support provided by the government of Bangladesh for primary schools.

In order to achieve the main objective, the following specific objectives must be achieved as follows:

i. To justify the ICT supporting facilities in primary schools and how much implementation they may achieved. ii. To justify by using a model how much implementation of ICT support in primary schools has been done by each division in Bangladesh.

iii. To suggest some key points that how can the Government of Bangladesh be implemented the ICT support in primary schools.

\section{Methodology}

\section{A. Study design}

A model has developed for the measuring the ICT implementation status in the e-primary schools of Bangladesh.

\section{B. Study population}

The study has been selected 100 primary schools from Rajshahi division, 100 primary schools from Khulna division, 100 primary schools from Dhaka division, 100 primary schools from Chittagong division, 100 primary schools from Barisal division, 100 primary schools from Sylhet division, 100 primary schools from Rangpur division, 100 primary schools from Mymenshing division. A total 800 primary schools from the e-primary school systems of Bangladesh is the population of the study.

\section{Sampling design}

The sample size is 800 primary schools among the eight divisions which was taken from the e-primary school systems database under the directorate of primary education of Bangladesh.

\section{DATA ANALYSIS}

In this model from the fig.1., there are five major factors f1(Projectors), f2 (PC/Laptop), f3(Projector Screen), f4 (Modem), f5(Printer) and three sub factors for f1 (f1.1, f1.2, f1.3 respectively for Electricity, ICT skilled Teachers, ICT oriented class facilities), three sub factors for f2 ( $\mathrm{f} 2.1, \mathrm{f} 2.2$, f2.3 respectively for projector, projector screen, electricity), three sub factors for $\mathrm{f} 3$ ( $\mathrm{f} 3.1$, f3.2, f3.3 respectively for projector, PC/Laptop, electricity), two sub factors for $\mathrm{f} 4$ ( $\mathrm{f} 4.1, \mathrm{f} 4.2$ respectively for electricity, PC/Laptop), two sub factors for f5( f5.1, f5.2 respectively for PC/Laptop, electricity).

In this model each factor is considered as equal to 10 weight, by that reason the $\mathrm{f} 1$ is $10, \mathrm{f} 2$ is $10, \mathrm{f} 3$ is $10, \mathrm{f} 4$ is 10 and $\mathrm{f5}$ is 10 then the full weight is $(\mathrm{f} 1+\mathrm{f} 2+\mathrm{f} 3+\mathrm{f} 4+\mathrm{f} 5=50) 50$. If a school can get 50 out of 50 then it can be considered as best ICT implemented primary schools in Bangladesh. So, implementation of ICT in school is the sum of $\mathrm{f} 1, \mathrm{f} 2, \mathrm{f} 3, \mathrm{f} 4$ and $\mathrm{f} 5$.

$$
\begin{gathered}
\text { Here, } f 1=10, f 1.1=5, f 1.2=2.5, f 1.3=2.5 \\
f 2=10, f 2.1=2.5, f 2.2=2.5, f 2.3=5 \\
f 3=10, f 3.1=3.5, f 3.2=3, f 3.3=3.5 \\
f 4=10, f 4.1=2, f 4.2=8 \\
f 5=10, f 5.1=5, f 5.2=5
\end{gathered}
$$


From the fig.2.in this model $\mathrm{f} 1$ (Projector) is equal to 10 weight and this 10 is divided into three segments first is $\mathrm{f} 1.1=5$ (electricity), second is $\mathrm{f} 1.2=2.5$ (ICT skilled teachers) and third is $\mathrm{f1.3}=2.5$ (ICT oriented class facilities). In the second formula, f2 (PC/Laptop) is equal to 10 weight and this 10 is divided into three segments first is $\mathrm{f} 2.1=2.5$ (projector), second is $\mathrm{f} 2.2=2.5$ (projector screen) and third is $\mathrm{f} 2.3=5$ (electricity). In the third formula, f3 (Projector screen) is equal to 10 weight and this 10 is divided into three segments first is $\mathrm{f} 3.1=3.5$ (projector), second is $\mathrm{f} 3.2=3$ (PC/Laptop) and third is f3.3=3.5 (electricity). In the fourth formula, f4 (Modem) is equal to 10 weight and this 10 is divided into two segments first is $\mathrm{f} 4.1=2$ (electricity), second is $\mathrm{f} 4.2=8$ (PC/Laptop). In the fifth formula, f5 (Printer) is equal to 10 weight and this 10 is divided into two segments first is f5.1=5 (PC/Laptop), second is f5.2=5 (electricity).

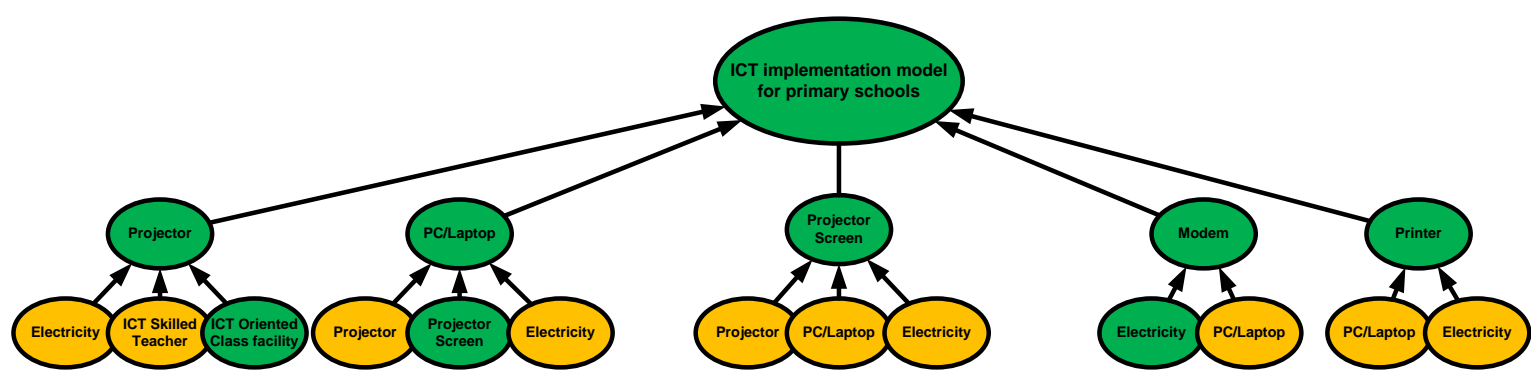

Fig. 1. Model of ICT implementation status in primary schools of Bangladesh

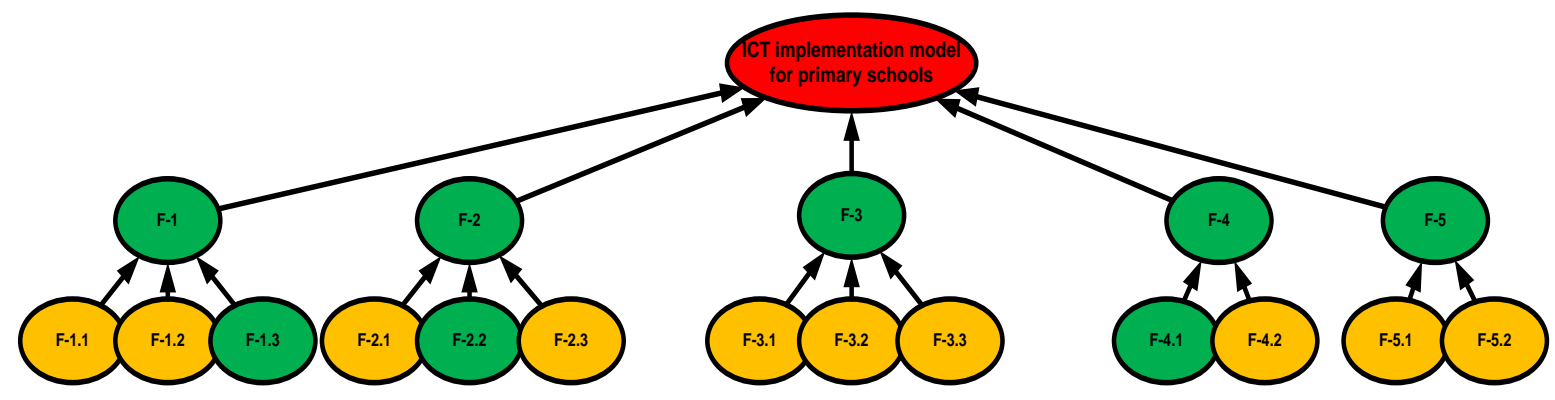

Fig.2. ICT implementation status model with factors

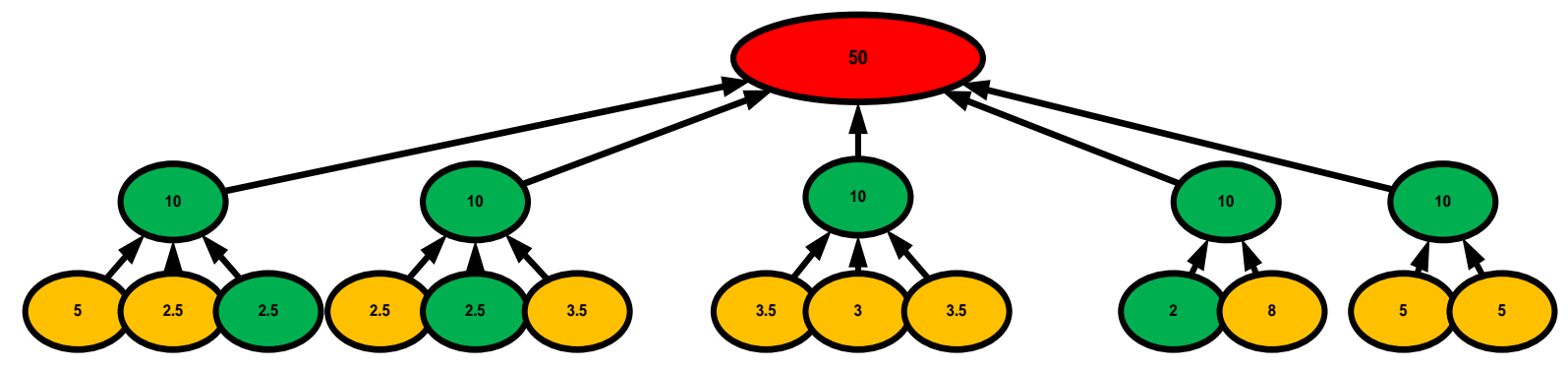

Fig. 3. ICT implementation status model with weights

Table 1. Number of ICT equipment provided by the government of Bangladesh in among 800 primary schools

\begin{tabular}{|c|c|c|c|c|c|c|c|c|}
\hline Divisions & Rajshahi & Khulna & Dhaka & Chittagong & Barisal & Sylhet & Rangpur & Mymenshing \\
\hline $\begin{array}{c}\text { No of } \\
\text { Computer }\end{array}$ & 10 & 3 & 0 & 3 & 0 & 5 & 8 & 0 \\
\hline $\begin{array}{c}\text { No of } \\
\text { Laptop }\end{array}$ & 90 & 93 & 29 & 9 & 90 & 90 & 14 & 91 \\
\hline $\begin{array}{c}\text { No of } \\
\text { Printer }\end{array}$ & 9 & 3 & 0 & 3 & 0 & 5 & 4 & 0 \\
\hline $\begin{array}{c}\text { No of } \\
\text { Projector }\end{array}$ & 28 & 37 & 6 & 5 & 89 & 90 & 7 & 90 \\
\hline $\begin{array}{c}\text { No of } \\
\text { Modem }\end{array}$ & 6 & 4 & 2 & 0 & 0 & 2 & 3 & 3 \\
\hline
\end{tabular}

Source: E-primary school systems 2019 
Table 2. Number of ICT equipment provided by the government of Bangladesh in among 800 schools

\begin{tabular}{|c|c|c|c|c|c|c|c|c|c|}
\hline Divisions & Rajshahi & Khulna & \multicolumn{2}{|c|}{ Dhaka } & Chittagong & Barisal & Sylhet & Rangpur & Mymenshing \\
\hline \multicolumn{7}{|c|}{ Comparison of Computer/ Laptop to } \\
\hline $\begin{array}{c}\text { Printer } \\
\text { (in \%) }\end{array}$ & $9 \%$ & $3.13 \%$ & $3.45 \%$ & $25 \%$ & $1.11 \%$ & $5.26 \%$ & $18.18 \%$ & $1.11 \%$ \\
\hline $\begin{array}{c}\text { Projector } \\
\text { (in \%) }\end{array}$ & $28 \%$ & $38.54 \%$ & $20.69 \%$ & $41.67 \%$ & $98.89 \%$ & $94.74 \%$ & $31.82 \%$ & $98.90 \%$ \\
\hline $\begin{array}{c}\text { Modem } \\
\text { (in \%) }\end{array}$ & $6 \%$ & $4.17 \%$ & $6.90 \%$ & $8.33 \%$ & $1.11 \%$ & $2.11 \%$ & $13.64 \%$ & $3.30 \%$ \\
\hline
\end{tabular}

Source: E-primary school systems 2019

Table 3. Division wise ICT equipment's and their supporting capacity

\begin{tabular}{|c|c|c|c|c|}
\hline \multirow{2}{*}{ Division } & $\begin{array}{c}\text { ICT Equipment out of 800 } \\
\text { e-primary schools }\end{array}$ & $\begin{array}{c}\text { Computer/ } \\
\text { Laptop }\end{array}$ & Projector & Modem \\
\hline \multirow{2}{*}{ Rajshahi } & ICT equipment & $100 \%$ & $28 \%$ & $6 \%$ \\
\cline { 2 - 5 } & Supporting capacity for ICT equipment & $28 \%$ & $50 \%$ & $100 \%$ \\
\hline \multirow{2}{*}{ Khulna } & ICT equipment & $96 \%$ & $37 \%$ & $4 \%$ \\
\cline { 2 - 5 } & Supporting capacity for ICT equipment & $39 \%$ & $100 \%$ & $100 \%$ \\
\hline Dhaka & ICT equipment & $29 \%$ & $6 \%$ & $4 \%$ \\
\cline { 2 - 5 } & Supporting capacity for ICT equipment & $20 \%$ & $100 \%$ & $100 \%$ \\
\hline Chittagong & ICT equipment & $12 \%$ & $5 \%$ & $0 \%$ \\
\cline { 2 - 5 } & Supporting capacity for ICT equipment & $41 \%$ & $100 \%$ & $0 \%$ \\
\hline Barisal & ICT equipment & $90 \%$ & $89 \%$ & $0 \%$ \\
\cline { 2 - 5 } & Supporting capacity for ICT equipment & $99 \%$ & $100 \%$ & $0 \%$ \\
\hline Sylhet & ICT equipment & $95 \%$ & $89 \%$ & $2 \%$ \\
\cline { 2 - 5 } & Supporting capacity for ICT equipment & $94 \%$ & $100 \%$ & $100 \%$ \\
\hline \multirow{2}{*}{ Rymenshing } & ICT equipment & $92 \%$ & $7 \%$ & $3 \%$ \\
\cline { 2 - 5 } & Supporting capacity for ICT equipment & $100 \%$ & $100 \%$ \\
\hline
\end{tabular}

From the table 1. ,it was shown that in Rajshahi division, out of 100 primary schools from the e-primary school systems, 100 schools have one PC or Laptop, 9 schools have printers, 28 schools have projectors and 6 schools have modem facilities; 96 schools have one PC or Laptop, 3 schools have printers,37 schools have projectors and 4 schools have modem facilities in Khulna division; 29 schools have one PC or Laptop, no schools have printers, 6 schools have projectors and 2 schools have modem facilities in Dhaka division; 12 schools have one PC or Laptop, 3 schools have printers, 5 schools have projectors and no schools have modem facilities in Chittagong division; 90 schools have one PC or Laptop, no schools have printers, 89 schools have projectors and 2 schools have modem facilities in Barisal division; 95 schools have one PC or Laptop, 5 schools have printers,90 schools have projectors and 2 schools have modem facilities in Sylhet division; 22 schools have one
PC or Laptop, 4 schools have printers, 7 schools have projectors and 3 schools have modem facilities in Rangpur division; 91 schools have one PC or Laptop, no schools have printers, 90schools have projectors and 3 schools have modem facilities in Mymenshing division

In the table 2. the calculation was done on the basis total number of computer/Laptop in comparison to printer, projector and modem. From the table 2..it was drawn that the Rajshahi division the comparison to the laptop or computer to printer utilization rate is $9 \%$,projector utilization rate is $28 \%$,modem utilization rate is $6 \%$; in Khulna division the comparison to the laptop or computer to printer utilization rate is $3.13 \%$,projector utilization rate is $38.54 \%$, modem utilization rate is $4.17 \%$; in Dhaka division the comparison to the laptop or computer to printer utilization rate is $3.45 \%$,projector utilization rate is $20.69 \%$,modem utilization rate is $6.90 \%$; in Chittagong division the comparison to the laptop or computer to 
printer utilization rate is $25 \%$,projector utilization rate is $41.67 \%$,modem utilization rate is $8.33 \%$; in Barisal division the comparison to the laptop or computer to printer utilization rate is $1.11 \%$,projector utilization rate is $98.89 \%$,modem utilization rate is $1.11 \%$; in Sylhet division the comparison to the laptop or computer to printer utilization rate is $5.26 \%$,projector utilization rate is $94.74 \%$,modem utilization rate is $2.11 \%$; in Rangpur division the comparison to the laptop or computer to printer utilization rate is $18.18 \%$,projector utilization rate is $31.82 \%$, modem utilization rate is $13.64 \%$; in Mymenshing division the comparison to the laptop or computer to printer utilization rate is $1.11 \%$,projector utilization rate is $98.90 \%$, modem utilization rate is $3.30 \%$.

From the Table 3. it was concluded that in Rajshahi division there was $100 \%$ computer or laptop in 100 from e-primary school but supporting capacity of PC/Laptop was $28 \%$, as the same way $28 \%$ schools has projector capacity but supporting capacity has $50 \%$, in $6 \%$ school there was modem facility and $100 \%$ supporting facility for modem. In Khulna division there was $96 \%$ computer or laptop in 100 from e-primary school but supporting capacity of PC/Laptop was 39\%, as the same way $37 \%$ schools has projector capacity but supporting capacity has $100 \%$, in $4 \%$ school there was modem facility and $100 \%$ supporting facility for modem. In Dhaka division there was $29 \%$ computer or laptop in 100 from e-primary school but supporting capacity of PC/Laptop was $20 \%$, as the same way $6 \%$ schools has projector capacity but supporting capacity has $100 \%$, in $4 \%$ school there was modem facility and $100 \%$ supporting facility for modem. In Chittagong division there was $12 \%$ computer or laptop in 100 from e-primary school but supporting capacity of PC/Laptop was $41 \%$, as the same way $5 \%$ schools has projector capacity but supporting capacity has $100 \%$, in $0 \%$ school there was modem facility and $0 \%$ supporting facility for modem. In Barisal division there was $90 \%$ computer or laptop in 100 from e-primary school but supporting capacity of PC/Laptop was $99 \%$, as the same way $89 \%$ schools has projector capacity but supporting capacity has $100 \%$, in $0 \%$ school there was modem facility and $0 \%$ supporting facility for modem. In Sylhet division there was $100 \%$ computer or laptop in 100 from e-primary school but supporting capacity of PC/Laptop was $28 \%$, as the same way $28 \%$ schools has projector capacity but supporting capacity has $50 \%$, in $6 \%$ school there was modem facility and $100 \%$ supporting facility for modem.

From the table 3. in Rangpur division there was 22\% computer or laptop in 100 from e-primary school but supporting capacity of PC/Laptop was $32 \%$, as the same way $7 \%$ schools has projector capacity but supporting capacity has $100 \%$, in $3 \%$ school there was modem facility and $100 \%$ supporting facility for modem. In Mymenshing division there was $91 \%$ computer or laptop in 100 from e-primary school but supporting capacity of PC/Laptop was $99 \%$, as the same way $90 \%$ schools has projector capacity but supporting capacity has $100 \%$, in $3 \%$ school there was modem facility and $100 \%$ supporting facility for modem

\section{FINDINGS}

i. In Bangladesh most of the primary schools have been introduced with ICT and ICT facilities. But in Dhaka division the rate of ICT facilities and support provided by the Government of Bangladesh $(\mathrm{GoB})$ is lowest among all other divisions in Bangladesh.

ii. Government of Bangladesh (GoB) has provided one or two or three ICT equipment for most of the primary schools in Bangladesh, such as one school get a Laptop and another school get a projector but none can get all the ICT equipment and support.

iii. In some cases, some primary schools get all ICT equipment but they don't get any ICT supporting facilities that means some school have their PC, projector, projector screen and modem by the Government of Bangladesh (GoB). This ICT equipment and facilities can't they utilized because of ICT trained or ICT oriented class room facilities.

iv. There is a huge limitation to coordinate the ICT support provider and ICT support receivers. The provider just has provided the ICT facilities but they don't look in to the implementation status. On the other hand, the ICT support recipient just have received the ICT support but they don't have any capacity to use the ICT support. As a result, many school have $100 \%$ ICT facilities but they can implement only $20-30 \%$ of their ICT support at best which was identified in this study.

\section{RECOMMENDATIONS}

i. Every division should get the equal priority in getting ICT support. All out efforts (ICT facilities \& ICT equipment) should be introduced in all primary schools in Bangladesh. Though the ICT implementation in Bangladesh has been going on step by step process, the proper return can't get until all kind of ICT facilities provided to all primary schools.

ii. The Government of Bangladesh should re-modified their planning in the implementation of ICT support in primary schools. At the same time all kinds of ICT equipment and facilities should be provided that can make a good sign for implementing ICT in primary schools.

iii. The current process is one school get one laptop another school get a projector and other school get a projector screen but no school get all kinds of ICT equipment and facilities at the same time as a result no one can go to their proper implementation stage.

iv. Government should be introduced one by one ICT enable (all ICT equipment and supporting facilities) model primary school that will be set up in each Upazila or Thana. Then step by step it will be expanded each and every year.

v. Training facilities for the primary school's teacher who usually teach the ICT related subjects, should 
be introduced all primary schools in Bangladesh.

\section{CONCLUSIONS}

ICT have been using in various primary schools in Bangladesh though it's in small amount, it can mostly impact on our future nation. The Government of Bangladesh (GoB) has taken ICT use in primary education and it create in huge success. In this paper all elements of ICT being used in primary schools in Bangladesh has been considered in a model. This model has analyzed and examined how it works and what impact of it on our future nation. The future research can identify the planning and execution limitation of ICT used not only in primary schools but also in seconday \& higher secondary schools for Bangladesh.

\section{REFERENCES}

[1] Oddershede, A., Donoso, J., Farias, F., \& Jarufe, P. (2015). ICT Support assessment in primary school teaching and learning through AHP. Procedia Computer Science, 55(Itqm), 149-158. https://doi.org/10.1016/j.procs.2015.07.023

[2] Oyaid, A. A. (2009). Education Policy in Saudi Arabia and its Relation to Secondary School Teachers' ICT Use, Perceptions, and Views of the Future of ICT in Education. Education, (May 2009). https://doi.org/10.1186/14712156-6-S1-S121

[3] Dewan, Roohi, Zakia;Ashafunnessa, H. M. L. (2004). A study on decentralization of secondary education administration in Bangladesh: The necessity and effectiveness of governing bodies of non-government. NAEM Journal.

[4] Andreea, O., \& Creţu, C. (2015). Ict Support and Ict Use in Romanian Secondary Education. The 11th International Scientific Conference ELearning and Software for Education, (March), 188-193. https://doi.org/10.12753/2066-026X-15-209

[5] Blignaut, S., \& Els, C. (2009). Towards a research framework for ICT use in developing contexts. IMETI 2009 - 2nd International Multi-Conference on Engineering and Technological Innovation, Proceedings, 2(June 2014), 245-250.

[6] Nikolopoulou, K., \& Gialamas, V. (2016). Barriers to ICT use in high schools: Greek teachers' perceptions. Journal of Computers in Education, 3(1), 59-75. https://doi.org/10.1007/s40692-015-0052.

[7] Hsu, S., \& Rd, R. (2000). Teacher' s background and ICT uses at schools in Taiwan. Educational Media and Technology Yearbook, (106), 2-4.

[8] Lozoya, S. V. M., Quintana, J. T., Armenta, J. A., \& Pérez, M. V. (2018). Contextual attribute variables in the use of ICT in primary level students from Southern Sonora, Mexico. Estudios Sobre Educacion, 35, 499-515. https://doi.org/10.15581/004.34.499-515.

[9] Aydin, M. K., Semerci, A., \& Gürol, M. (2016). Teachers' attitude towards ICT use in secondary schools: A scale development study. Proceedings of the 13th International Conference on Cognition and Exploratory Learning in the Digital Age, CELDA 2016, (March), 375-377.

[10] Tezci, E. (2010). Attitudes and knowledge level of teachers in ICT use: The case of Turkish teachers. International Journal of Human Sciences, 7(2), 19-44. Retrieved from http://citeseerx.ist.psu.edu/viewdoc/download?doi=10.1.1.
$881.8297 \&$ rep=rep1\&type=pdf\%0Ahttp://j humansciences.com/ojs/index.php/IJHS/article/view/797.

[11] Mulenga, E. M. (2018). Zambian Teachers 'Profiles of ICT Use in Mathematics Pedagogy . ZAMBIAN TEACHERS , PROFILES OF ICT USE IN MATHEMATICS PEDAGOGY. Journal of Basic and Applied Research International, 24(October), 137-148.

[12] Ghamrawi, N. (2013). The Relationship between the Leadership Styles of Lebanese Public School Principals and Their Attitudes towards ICT versus the Level of ICT Use by Their Teachers. Open Journal of Leadership, 02(01), 11-20. https://doi.org/10.4236/oj1.2013.21002

[13] Ayere, M. A., Odera, F. Y., \& Agak, J. O. (2010). Elearning in secondary schools in Kenya: A case of the NEPAD E-schools. Educational Research and Reviews, 5(5), 218-223.

[14] Bulut, O., \& Cutumisu, M. (2018). When technology does not add up: ICT use negatively predicts mathematics and science achievement for finnish and Turkish students in PISA 2012. Journal of Educational Multimedia and Hypermedia, 27(1), 25-42.

[15] Rahaman, M. M., \& Akter, N. (2017). ICT Used In Education Sector Considering Primary and Secondary Level Schools in Rural Areas: A Study of Sylhet Division in Bangladesh. IOSR Journal of Business and Management 19(04), 01-06. https://doi.org/10.9790/487x-1904020106

[16] Rahaman, M. (2017). The Effects of Mobile Phone Use on Human Behaviors: A Study of Developing Country Like Bangladesh. International Journal of Information Technology and Computer Science, 9(11), 48-56. https://doi.org/10.5815/ijitcs.2017.11.05

[17] Cox, A., Jament, J., \& Tarry, E. (2011). An investigation into parental expectations of Primary schooling and the support provided by schools to a single Keralite community in an English county. Procedia - Social and Behavioral Sciences, 15(December), 66-71. https://doi.org/10.1016/j.sbspro.2011.03.052

[18] Etherington, M. (2008). E-learning pedagogy in the primary school classroom: The McDonaldization of education. Australian Journal of Teacher Education, 33(5), 29-54. https://doi.org/10.14221/ajte.2008v33n5.3.

[19] Tuparova, D., Kaseva, M., \& Tuparov, G. (2014). Development of Key Competences through ICT in Primary School. Procedia - Social and Behavioral Sciences, 116(September 2015), 2952-2956. https://doi.org/10.1016/j.sbspro.2014.01.686

[20] Verhoeven, J. C., Heerwegh, D., \& De Wit, K. (2016). ICT learning experience and research orientation as predictors of ICT skills and the ICT use of university students. Education and Information Technologies (Vol. 21). https://doi.org/10.1007/s10639-014-9310-3

[21] World Bank. (2013). Seeding fertile ground: Education that works for Bangladesh. Bangladesh Education Sector Review, (80613).

[22] Campbell, M. (2004). What is the Place of Innovative ICT Uses in School Counseling? Issues in Informing Science and Information Technology, 1(January), 0133-0140. https://doi.org/10.28945/725

[23] Durnali, M. (2013). The Contributions of E-School, a Student Information Management System, to the Data Processes, Environment, Education and Economy of Turkey. The Asian Conference on Technology in the Classroom 2013, (January 2013), 170-184. Retrieved from www.iafor.org

[24] Popa, O.-R., \& Bucur, N.-F. (2015). Romanian Primary School Teachers and ICT. Proceedings of the 10th 
International Conference on Virtual Learning, (November) 192-198.

[25] Cruz, E. (2018). Pupils' representations about the curricular integration of ICT in primary school education. Educacao $e$ Pesquisa, 44(1). https://doi.org/10.1590/S1678-4634201707157951

[26] Luaran, J. E., \& Jain, J. (2014). ICT integration in classrooms: the educators' perspective based on their schooland home ICT use. ESTEEM Academic Journal, 10(1), 66-74.

[27] Suratno, A., \& Aydawati, E. N. (2017). Exploring Students Perception and ICT Use in Indonesian High Schools. Celt: A Journal of Culture, English Language Teaching \& Literature, $16(2)$, https://doi.org/10.24167/celt.v16i2.735

[28] Ramharai, V., \& Goodoory, K. (2003). ICT in Primary Schools of Mauritius: Policy and Practice. International Conference on Open and Online Learning, (July).

[29] Islam, N., Helal, A. M., \& Yildirim, A. (2019). Primary School Governance in Bangladesh : A Practical Overview of National Education Policy-2010 Primary School Governance in Bangladesh: A Practical Overview of National Education Policy- 2010 BRAC Institute of Educational Development ( BIET ), BRAC University , Dhaka , Bangladesh, (March). https://doi.org/10.20533/ijcdse.2042.6364.2018.0475

[30] Sultana, M., \& Haque, M. S. (2018). The Cause of Low Implementation of ICT in Education Sector Considering Higher Education: A Study on Bangladesh. Canadian Social Science, $14(12), \quad 67-73$. https://doi.org/10.3968/10804

[31] Obaydullah, A. K. M. and M. A. R. (2019). Use of ICT for Primary science Teaching and Learning at the Primary Schools in Bangladesh. International Journal of Research and Innovative Ideas in Education, V(February), 642-651.

[32] Rahaman, M. M. (2018). Addiction of Information and Communication Technology (ICT) and Internet by the Bangladeshi University Students and Its Impact on Their Future. International Journal of Information Technology and Computer Science, 10(8), 56-68. https://doi.org/10.5815/ijitcs.2018.08.08

[33] Chagas, I. (2005). Promoting ICT Use In Portuguese Schools PROMOTING ICT USE IN PORTUGUESE SCHOOLS . A CASE OF SCHOOL-UNIVERSITY COLLABORATION Isabel Chagas João Sousa Centro Ciência Viva , Amadora Giselia Piteira Paula Mano Rosa Tripa Escola Secundária da Ramada, Odivelas, (January).

[34] Profile, S. E. E. (2017). Assessment of ICT Use in Government Schools of Kalmunai Central Zone , Sri Lanka, $2017 \quad$ (December). https://doi.org/10.13140/2.1.4066.4007
[35] Schulz-Zander, R., \& Eickelmann, B. (2009). Teacher Collaboration Concerning ICT-Use and its Essential Conditions, (March), 1-5. Retrieved from http://www.ifsdortmund.de/files/WCCE2009_pap275.pdf

[36] Semerci, A., \& Aydın, M. K. (2018). Examining High School Teachers' Attitudes towards ICT Use in Education. International Journal of Progressive Education, 14(2), 93105. https://doi.org/10.29329/ijpe.2018.139.7

[37] Tietjen, K. (2003). The Bangladesh Primary Education Stipend Project: A Descriptive Analysis. Research Bulletin, (November), 46.

[38] Zaranis, N. (2014). Research on e-Learning and ICT in Education. Research on E-Learning and ICT in Education, (October), 0-1. https://doi.org/10.1007/978-1-4614-6501-0

\section{Authors' Profiles}

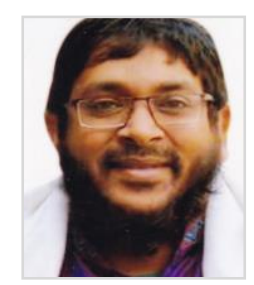

Dr. Wahiduzzaman Khan is an associate professor and Head of Business Administration Department at Leading University Bangladesh. Dr. Khan has 13 years of full time teaching and research experience at University level. He has completed his BBA, MBA and $\mathrm{PhD}$ from University of Rajshashi with academic excellence. In the field of e-learning, e-banking, consumer behavior and socio-economic; he has a key interest in this areas. In his academic career he has published 17 researches in home and abroad. In the recent year, he has got Dr. Said Ragib Ali research award- 2019.

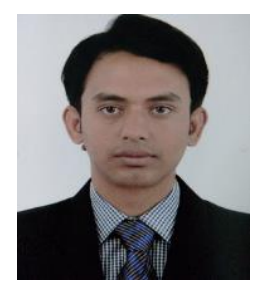

Md. Mahbobor Rahaman is a Lecturer in the major Management Information Systems at the Department of Business Administration, Leading University Bangladesh. He has completed his BBA and MBA from University of Dhaka, Bangladesh. In his teaching and research career, he has been focusing on using ICT in education, women empowerment, rural development, remote area development, ICT addictions, data mining, big data etc. $\mathrm{Mr}$ Rahaman has 5 years of teaching and research experiences at different universities in Bangladesh. He has published 8 articles, 3 project funds and presented 4 papers in national \& international conferences.

How to cite this paper: Wahiduzzaman Khan, Md. Mahbobor Rahaman, " Measuring the Performance of e-Primary School Systems in Bangladesh ", International Journal of Modern Education and Computer Science(IJMECS), Vol.12, No.1, pp. 35-41, 2020.DOI: 10.5815/ijmecs.2020.01.05 